\title{
Assembly of organic moiety with metal-oxide cluster to generate a new three dimensional supramolecular/hydrogen bonded network based on isopolymolybdate
}

\author{
DONIA ZAMMEL ${ }^{\mathrm{a}, \mathrm{b}, *}$, ICHRAF NAGAZI ${ }^{\mathrm{a}, \mathrm{b}}$ and AMOR HADDAD ${ }^{\mathrm{a}, \mathrm{b}}$ \\ aLaboratoire des Matériaux, Cristallochimie et thermodynamique appliqué, Université Tunis El Manar, \\ Faculté des sciences de Tunis, Tunis, Tunisia

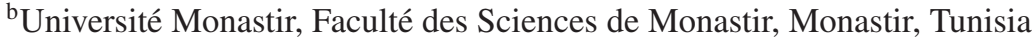 \\ e-mail: doniazammel@yahoo.fr
}

MS received 10 January 2016; revised 6 May 2016; accepted 9 May 2016

\begin{abstract}
A new octa-molybdate formulated as $\left(\mathrm{C}_{2} \mathrm{H}_{6} \mathrm{~N}_{4}\right)_{2}\left[\beta-\mathrm{Mo}_{8} \mathrm{O}_{26}\right] \cdot 4 \mathrm{H}_{2} \mathrm{O}(\mathbf{1})$ has been isolated by conventional solution method and structurally characterized by single-crystal X-ray diffraction method, IR spectroscopy, UV-Vis absorption, thermogravimetric analysis and cyclic voltammetry. Compound $\mathbf{1}$ crystallizes in the Triclinic system, space group P-1 with unit cell dimensions, $a=8.348$ (2) $\AA$, $b=10.154$ (2) $\AA$, c $=10.823$ (3) $\AA, \alpha=68.35^{\circ}(2), \beta=71.59^{\circ}(2), \gamma=78.55^{\circ}(2), V=805.5$ (3) $\AA^{3}$, and $Z=2$. The crystal structure of 1 is built up from octa-molybdate $\left[\beta-\mathrm{Mo}_{8} \mathrm{O}_{26}\right]^{4-}$ clusters connected through hydrogen-bonding interactions into a three-dimensional supramolecular network.
\end{abstract}

Keywords. Octa-molybdate; X-ray diffraction; electrochemical measurements; crystal structure; polyoxometalates.

\section{Introduction}

Polyoxometalates (POMs) are an immense class of metal-oxygen cluster compounds, which exhibit compositional diversity and structural versatility, as well as molecular identity in both the solid state and solutions. ${ }^{1}$ POMs, as a unique class of nanosized metal oxide clusters with abundant topologies and oxygen-rich surface, have exhibited remarkable properties in the field of catalysis, medicine and optics, etc. ${ }^{2-7}$

Furthermore, it is noteworthy that an important field in the polyoxomolybdates is the structural chemistry of the well-known polyoxomolybdate anion, $\left[\mathrm{Mo}_{8} \mathrm{O}_{26}\right]^{4-}$, it was first described in organic-inorganic hybrid materials by Hagrman et al. ${ }^{9}$ Up to now, eight isomeric forms, the $\alpha-, \beta-, \gamma-, \delta-, \varepsilon-, \zeta-, \eta$-, and $\theta$-isomer, were prepared in discrete presentations. ${ }^{10-12}$ This current description of the octa-molybdate structure, however, will focus on the two most prominent isomeric forms, $\left[\alpha-\mathrm{Mo}_{8} \mathrm{O}_{26}\right]^{4-}$ and $\left[\beta-\mathrm{Mo}_{8} \mathrm{O}_{26}\right]^{4-}$.

The $\left[\beta-\mathrm{Mo}_{8} \mathrm{O}_{26}\right]^{4-}$ is composed of eight distorted octahedra sharing corners and edges, the cluster framework can be visualized by, once again, referring back to the deca-vanadate structure. If one considers removal of two $\{$ MO6 $\}$ octahedra from the $\left\{\mathrm{V}_{10} \mathrm{O}_{28}\right\}$ cluster framework, this then creates the octa-nuclear arrangement found in the $\left[\beta-\mathrm{Mo}_{8} \mathrm{O}_{26}\right]^{4-}$ anion (see figure 1). ${ }^{13}$

\footnotetext{
*For correspondence
}

Recently, the interest is extended to the modification of POM structure by introduction of organic derivatives. ${ }^{14}$ As the POM anions contain many oxygen atoms which act as good hydrogen bond acceptors, bonding these POMs with organic molecules having many hydrogen atoms give rise to interesting supramolecular chemistry. ${ }^{15-17}$ The supramolecular interactions are mediated by various types of hydrogen bonds like $\mathrm{O}-\mathrm{H}-\mathrm{O}, \mathrm{N}-\mathrm{H}-\mathrm{O}, \mathrm{C}-\mathrm{H}-\mathrm{O}, \mathrm{O}-\mathrm{H}-\mathrm{N}$, etc. ${ }^{15,16}$ Recent progress in this area has generated many examples of 1-3D molecular frameworks with novel structure features. ${ }^{18,19}$

We report here an octa-molybdate of a new organic cation $\left(\mathrm{C}_{2} \mathrm{H}_{6} \mathrm{~N}_{4}\right)_{2}\left[\beta-\mathrm{Mo}_{8} \mathrm{O}_{26}\right] \cdot 4 \mathrm{H}_{2} \mathrm{O}$ (1), which displays a $3 \mathrm{D}$ framework through hydrogen bonding interactions between protonated cations, water molecule and $\left[\mathrm{Mo}_{8} \mathrm{O}_{26}\right]^{4-}$ anions.

\section{Experimental}

\subsection{General procedures}

All reagents and solvents for synthesis were purchased from commercial sources and used without further purification. Infrared spectrum was recorded at a room temperature on a Perkin-Elmer Spectrum Tow ATRFTIR, over the wave number range between 4000 and $400 \mathrm{~cm}^{-1}$. Thermogravimetric analysis (TG) was 

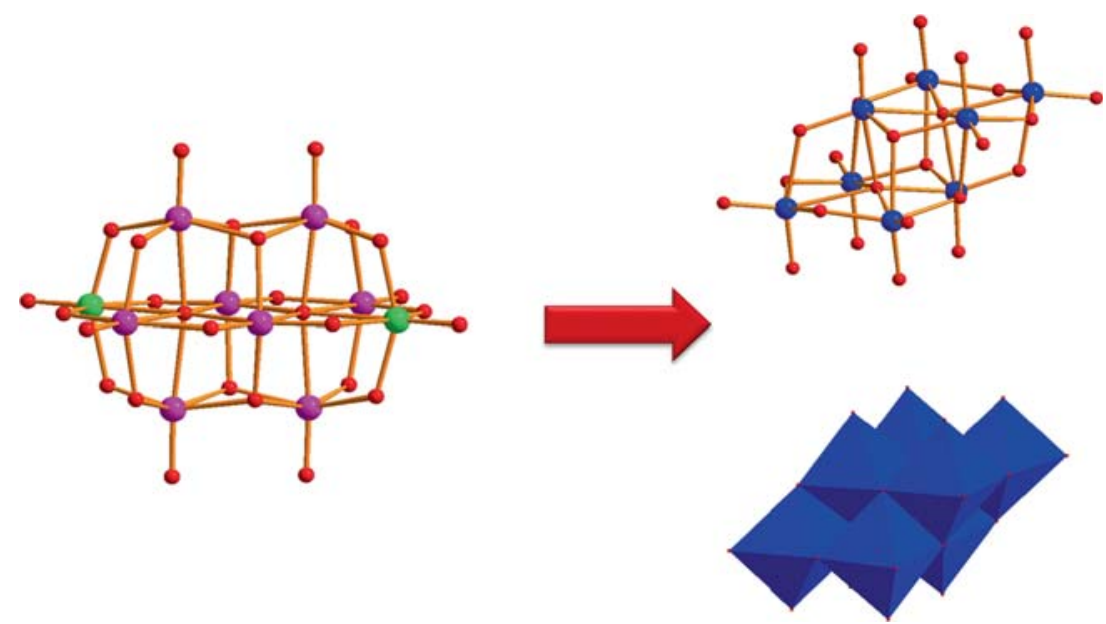

Figure 1. Left: Structural representation of the $\left[\mathrm{V}_{10} \mathrm{O}_{28}\right]^{6-}$ deca-vanadate anion. The two metal addenda, which can be considered to be removed in order to form the framework observed in $\left[\beta-\mathrm{Mo}_{8} \mathrm{O}_{26}\right]^{4-}$, are highlighted in light green. Top Right: Ball-and-stick representation of the $\left[\beta-\mathrm{Mo}_{8} \mathrm{O}_{26}\right]^{4-}$ anion. Bottom Right: Polyhedral representation showing the eight corner- and edgesharing $\{$ MoO6 $\}$ octahedra of the $\left[\beta-\mathrm{Mo}_{8} \mathrm{O}_{26}\right]^{4-}$ anion. Colour scheme: $\mathrm{V}$, purple and light green; Mo, blue (polyhedra); $\mathrm{O}$, red.

performed on Setaram Labsys Evo TG/ DSC $\left(1600^{\circ} \mathrm{C}\right)$ instrument with a heating rate of $10^{\circ} \mathrm{C} \mathrm{min}{ }^{-1}$. UV-Vis spectrum was measured using a Perkin-Elmer Lambda 19 spectrophotometer in the $180-800 \mathrm{~nm}$ range. Electrochemical measurements were carried out on $\mathrm{CHI}$ 660B electrochemical analyzer at room temperature. A conventional three-electrode system was used: glassy carbon as working electrode, $\mathrm{Ag} / \mathrm{AgCl}$ as the reference electrode and platinum wire as the counter electrode.

\subsection{Synthesis of $\left(\mathrm{C}_{2} \mathrm{H}_{6} \mathrm{~N}_{4}\right)_{2}\left[\beta-\mathrm{Mo}_{8} \mathrm{O}_{26}\right] \cdot 4 \mathrm{H}_{2} \mathrm{O}(\mathrm{I})$}

$\left(\mathrm{NH}_{4}\right)_{6} \mathrm{Mo}_{7} \mathrm{O}_{24} \cdot 4 \mathrm{H}_{2} \mathrm{O}(9 \mathrm{mmol}, 11.12 \mathrm{~g})$ was dissolved in $\mathrm{H}_{2} \mathrm{O}(20 \mathrm{~mL})$ and $\mathrm{MnSO}_{4}(1 \mathrm{mmol}, 0.151 \mathrm{~g})$ was added into the stirred solution. The $\mathrm{pH}$ of the mixture was carefully adjusted with dilute $\mathrm{H}_{2} \mathrm{SO}_{4}$ solution (2M) to approximately 4.0 , then $\left(\mathrm{C}_{2} \mathrm{H}_{4} \mathrm{~N}_{4}\right)(0.5 \mathrm{mmol}$, $0.042 \mathrm{~g})$ and $\mathrm{CaSO}_{4}(0.5 \mathrm{mmol}, 0.068 \mathrm{~g})$ were dissolved separately and added to the mixture solution with stirring. Afterwards, the solution was heated to $120^{\circ} \mathrm{C}$. After a few days, the colorless block crystals were deposited from the filtrate by evaporation at room temperature. The product cannot be obtained without $\mathrm{MnSO}_{4}$ and $\mathrm{CaSO}_{4}$ in the reaction system, although $\mathrm{Mn}$ and $\mathrm{Ca}$ are absent in the title compound. Elemental Anal. Found: C, 3.16; H, 1.44 and N, 7.91 (\%). Calcd: C, 3.36; H, 1.41 and N, $7.85(\%)$.

\subsection{IR spectroscopy}

IR-spectrum of compound $\left(\mathrm{C}_{2} \mathrm{H}_{6} \mathrm{~N}_{4}\right)_{2}\left[\beta-\mathrm{Mo}_{8} \mathrm{O}_{26}\right]$. $4 \mathrm{H}_{2} \mathrm{O}(\mathbf{1})$ is displayed in figure $\mathrm{S} 1$ (Supplementary
Information), which exhibits the characteristic bands associated with the building constituents from which material was synthesized: the polyoxoanion $\left[\mathrm{Mo}_{8} \mathrm{O}_{26}\right]^{4-}$ and organic groups. The $\left[\beta-\mathrm{Mo}_{8} \mathrm{O}_{26}\right]^{4-}$ cluster is characterized by two absorption bands in the range of $901-990 \mathrm{~cm}^{-1}$, corresponding to the $v$ (Mo$\mathrm{O}_{\mathrm{t}}$ ) absorption vibration. The absorption bands in the range of $450-866 \mathrm{~cm}^{-1}$ are attributed to $\delta\left(\mathrm{Mo}-\mu_{2}-\mathrm{O}\right)$ and $\delta\left(\mathrm{Mo}-\mu_{3}-\mathrm{O}\right)$ vibration. The features at 3057, $2846 \mathrm{~cm}^{-1}$ can be regarded as $v(\mathrm{~N}-\mathrm{H})$, and $v_{\mathrm{s}}(\mathrm{C}-\mathrm{H})$. The $v(\mathrm{O}-\mathrm{H})$ and $\delta(\mathrm{H}-\mathrm{O}-\mathrm{H})$ of water molecules appear at 3530,3200 and $1596 \mathrm{~cm}^{-1}$, respectively. Those at 1671,1424 and $1060 \mathrm{~cm}^{-1}$ could be ascribed to the stretching vibration modes of $v(\mathrm{C}=\mathrm{N}), v$ $(\mathrm{C}-\mathrm{N}),{ }^{20}$ and $v(\mathrm{~N}-\mathrm{N})$ groups.

\subsection{Crystal data}

X-ray intensity data were collected on an Enraf-Nonius CAD-4 diffractometer with monochromated graphite Mo $\mathrm{K}_{\alpha}$ radiation $(\lambda=0,71073 \AA) .{ }^{21}$ The reflections were corrected for Lorentz and polarization effects; an empirical absorption correction was also applied using $\Psi$-scan data. ${ }^{22}$ All the structures were solved by Patterson method using SHELXS-97, ${ }^{23}$ and refined by full-matrix least-squares on $\mathrm{F}^{2}$ using the SHELXL97 software. ${ }^{24}$ All non-hydrogen atoms were refined anisotropically. The hydrogen atoms attached to nitrogen and carbon atoms were fixed in ideal positions. The refinement of the structure leads to a residual factor $\mathrm{R}=0.030(w R 2=0.092)$ for 2807 independent 
observed reflections $[I>2 \sigma(I)]$ and 227 parameters. The crystal characteristics, data collection and refinement results are gathered in table 1.

\section{Results and Discussion}

\subsection{Structure description of Compound 1}

The single crystal X-ray diffraction analysis revealed that the asymmetric unit of compound $\mathbf{1}$ was composed of one-half of an octa-molybdate anion, two lattice water molecules and one $\left[\mathrm{C}_{2} \mathrm{H}_{6} \mathrm{~N}_{4}\right]^{2+}$ cations (figure 2).
The organic groups and water molecules reside between chains formed by inorganic octa-molybdate clusters as shown in figure 3 . The $\left[\mathrm{Mo}_{8} \mathrm{O}_{26}\right]^{4-}$ anion is a typical $\beta$-structure octa-molybdate, ${ }^{25}$ which is built up from eight distorted $\{\mathrm{MoO} 6\}$ edge-sharing octahedra. They can be described alternatively as two centrosymmetric $\left[\mathrm{Mo}_{4} \mathrm{O}_{13}\right]^{2-}$ units interleaving linked via bridging oxygen atoms (figure 4). The oxygen atoms can be divided into four groups, Mo- $\mathrm{O}_{\mathrm{t}}, \mathrm{Mo}-\mu_{2^{-}}$ $\mathrm{O}$, Mo- $-\mu_{3}-\mathrm{O}$ and $\mathrm{Mo}-\mu_{5}-\mathrm{O}$; the Mo-O bond lengths are in the range from 1.690 (3) to 2.462 (3) $\AA$ (table 2) and O-Mo-O angles are from 69.82 (11) to $173.24(14)^{\circ}$.

Table 1. Crystal structure data for $\mathbf{1}$.

\begin{tabular}{|c|c|}
\hline \multicolumn{2}{|l|}{ Crystal data } \\
\hline Compound & CCDC-1056979 \\
\hline Empirical formula & $\left(\mathrm{C}_{2} \mathrm{H}_{6} \mathrm{~N}_{4}\right)_{2}\left[\beta-\mathrm{Mo}_{8} \mathrm{O}_{26}\right] \cdot 4 \mathrm{H}_{2} \mathrm{O}$ \\
\hline Formula weight $\left(\mathrm{g} \mathrm{mol}^{-1}\right)$ & 1427.80 \\
\hline Crystal system & Triclinic \\
\hline Space group & P-1 \\
\hline $\mathrm{Z}$ & 2 \\
\hline \multicolumn{2}{|l|}{ Lattice parameters } \\
\hline$a\left(A^{\circ}\right)$ & $8.348(2)$ \\
\hline$b\left(A^{\circ}\right)$ & $10.154(2)$ \\
\hline$c\left(A^{\circ}\right)$ & $10.823(3)$ \\
\hline$\alpha\left(^{\circ}\right)$ & $68.35(2)$ \\
\hline$\beta\left(^{\circ}\right)$ & $71.59(2)$ \\
\hline$\gamma\left({ }^{\circ}\right)$ & $78.55(2)$ \\
\hline Cell volume $\left(\AA^{3}\right)$ & $805.5(3)$ \\
\hline Calculated density $(\mathrm{g} / \mathrm{cm})$ & 5.89 \\
\hline Absorption coefficient, $\mu\left(\mathrm{mm}^{-1}\right)$ & 6.23 \\
\hline$F_{000}$ & 1352 \\
\hline Crystal size $\left(\mathrm{mm}^{3}\right)$ & $0.1 \times 0.1 \times 0.1$ \\
\hline \multicolumn{2}{|l|}{ Intensity measurement } \\
\hline Diffractometer & Enraf-Nonius CAD4 \\
\hline Monochromator & Graphite \\
\hline Wavelength $\left[K_{\alpha}(\mathrm{Mo})\right]$ & $\lambda=0,71073 \AA$ \\
\hline Temperature & $293 \mathrm{~K}$ \\
\hline Theta range & $2.6^{\circ} / 27.0^{\circ}$ \\
\hline $\mathrm{h}, \mathrm{k}, \mathrm{l}$ range & $-10 / 1,-12 / 12,-13 / 13$ \\
\hline Number of measured reflections & 3735 \\
\hline Number of independent reflections & 3277 \\
\hline \multicolumn{2}{|l|}{ Structure determination } \\
\hline Unique reflection included $(I>2 \sigma(I))$ & 2807 \\
\hline Number of refined parameters & 227 \\
\hline Absorption correction & $\Psi-$ scan \\
\hline $\mathrm{T}_{\min }, \mathrm{T}_{\max }$ & $0.272,0.535$ \\
\hline$R\left[F^{2}>2 \sigma\left(F^{2}\right)\right], w R\left(F^{2}\right)$ & $0.03,0.092$ \\
\hline Weights & $\begin{array}{l}w=1 /\left[\sigma^{2}\left(F_{\mathrm{o}}^{2}\right)+(0.0499 P)^{2}\right. \\
\quad+1.9314 P] \\
\text { where } P=\left(F_{0}^{2}+2 F_{c}^{2}\right) / 3\end{array}$ \\
\hline Extinction coefficient & $0.0051(5)$ \\
\hline Goof S & 1.09 \\
\hline$\Delta \rho_{\operatorname{mim}} / \Delta \rho_{\max }\left(\mathrm{e} / \AA^{3}\right)$ & $-1.01 / 1.23$ \\
\hline
\end{tabular}



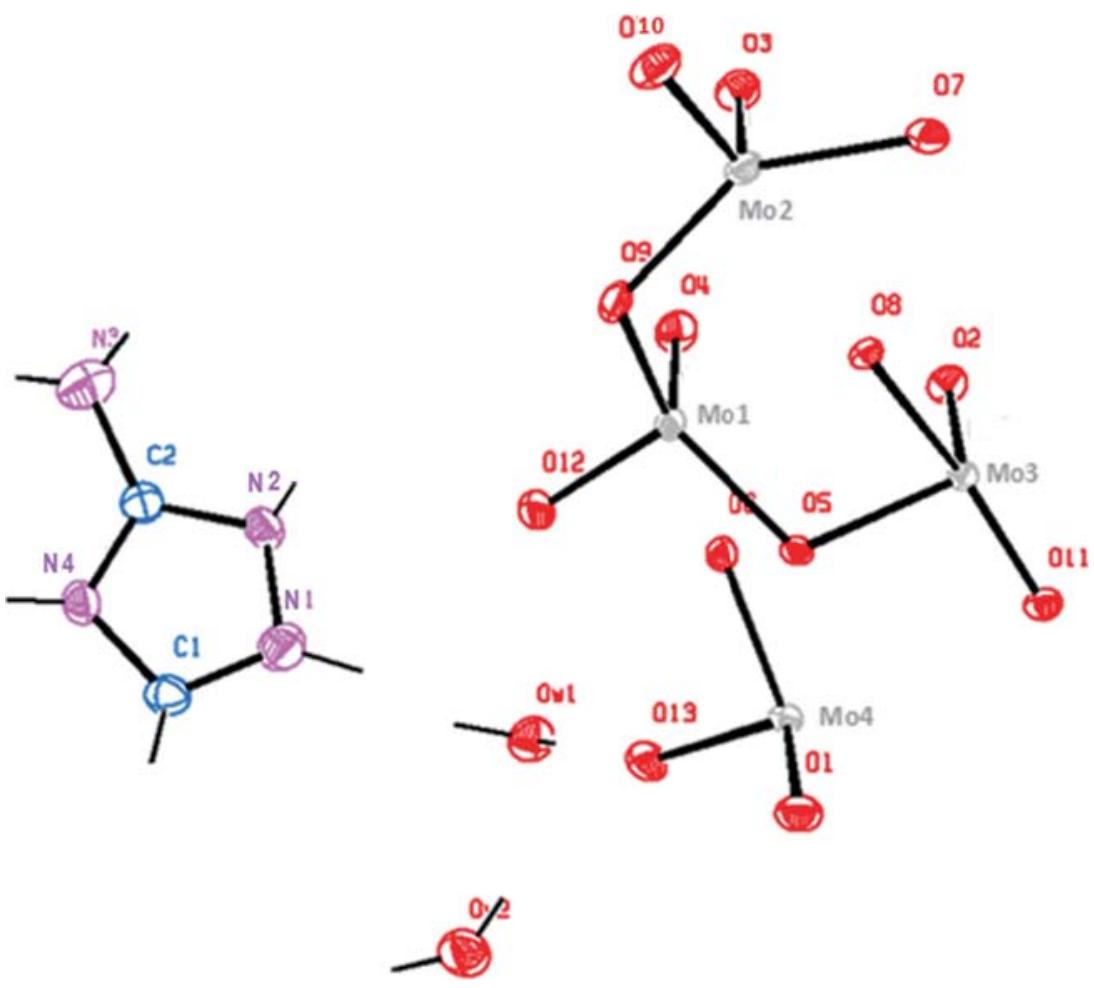

Figure 2. ORTEP diagram showing the asymmetric unit, with labeling of all the non-hydrogen atoms.

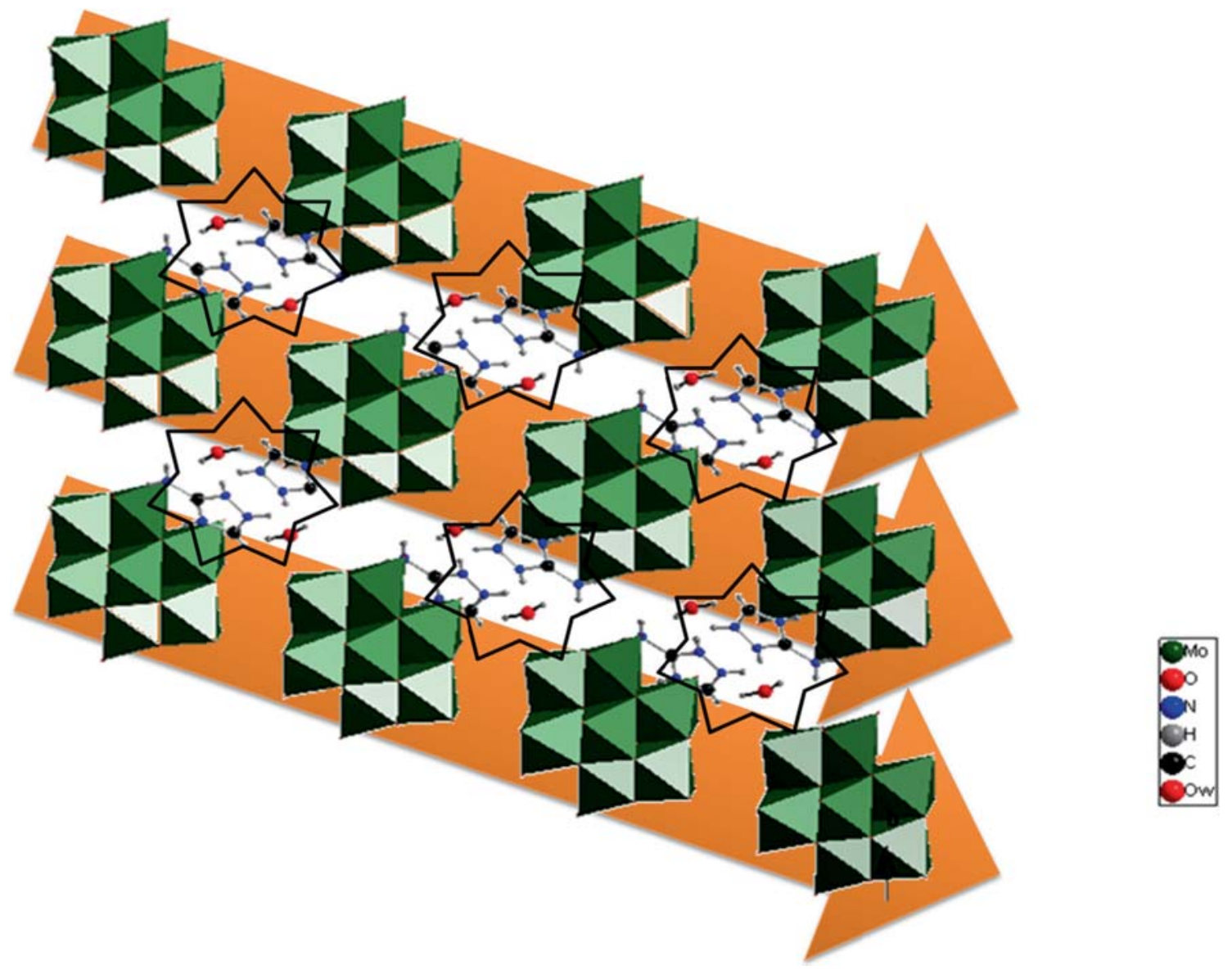

Figure 3. Packing view of compound 1 along the a axis, showing the arrangement of the chains $\left[\mathrm{Mo}_{8} \mathrm{O}_{26}\right]^{4-},\left[\mathrm{C}_{2} \mathrm{H}_{6} \mathrm{~N}_{4}\right]^{2+}$ cations and the lattice water molecules in the crystal structure. 

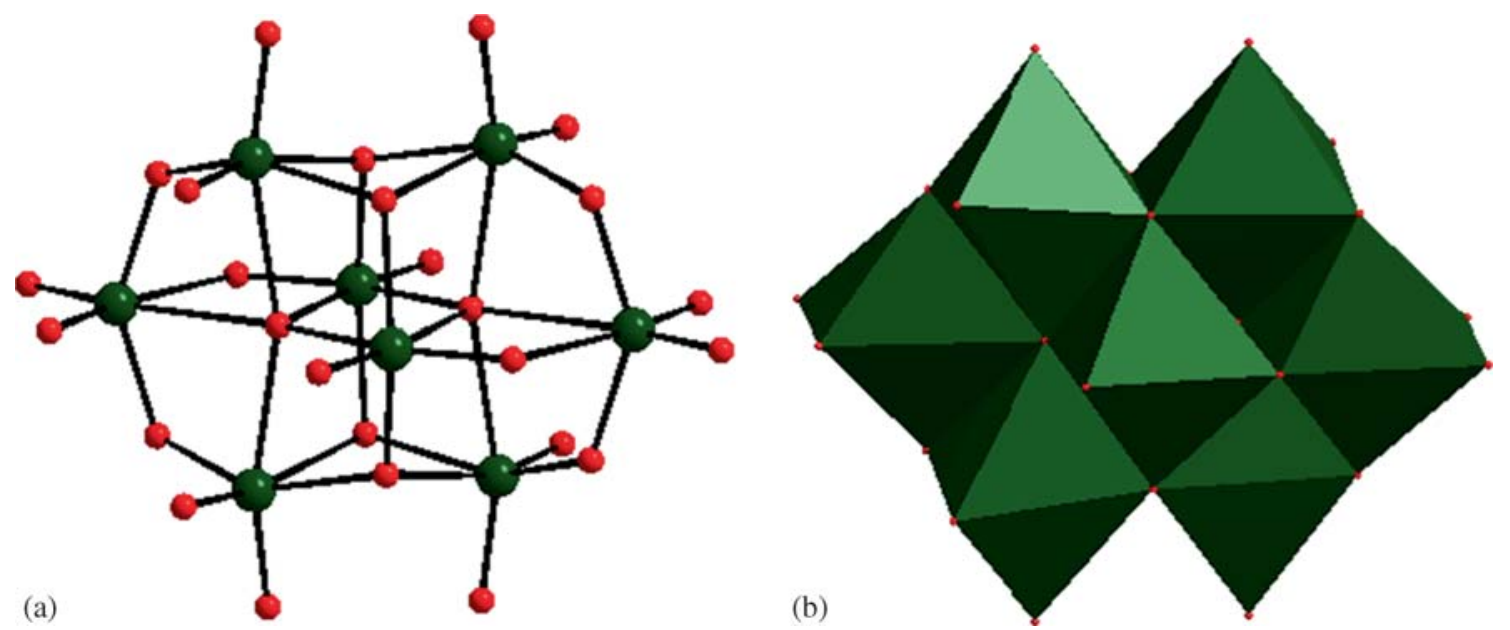

Figure 4. (a) Ball and stick representation of the $\beta\left[\mathrm{Mo}_{8} \mathrm{O}_{26}\right]^{4-}$ framework of 1. (b) Schematic polyhedral representation of $\beta\left[\mathrm{Mo}_{8} \mathrm{O}_{26}\right]^{4-}$ octamolybdate anions.

BVS calculations, ${ }^{26}$ revealed that all the molybdenum atoms have valence sums ranging from 5.909 to 5.976 , with an average value of 5.946, close to the ideal value of 6 for $\mathrm{Mo}^{\mathrm{VI}}$ (table 3). The result is consistent with the formula of compound 1 given by X-ray structure determination.

Owing to the presence of organic amine molecules and the molecular nature of the compounds, several varieties of hydrogen bonding interactions have been observed $(\mathrm{N}-\mathrm{H} \cdots \mathrm{O}, \mathrm{N}-\mathrm{H} \cdots \mathrm{OW} 1$ and $\mathrm{OW}-$ $\mathrm{H} \cdots \mathrm{O}$ ). Thus each $\left[\mathrm{C}_{2} \mathrm{H}_{6} \mathrm{~N}_{4}\right]^{2+}$ cation acts as a counterion and interacts through hydrogen bonds with one water molecule (N-H. . Ow1 2.118 $\AA$ ) and two different $\left[\mathrm{Mo}_{8} \mathrm{O}_{26}\right]^{4-}$ clusters through one $\mu_{3}$-oxo groups (O6) and one terminal oxygen (O12) with $\mathrm{N}-\mathrm{H}$...O interactions are from 1.971 to $2.467 \AA$ (figure 5).

Table 2. Selected bond lengths (Á) for compound $\mathbf{1}$.

\begin{tabular}{lccc}
\hline Bond lengths & & & \\
\hline Mo1-O12 & $1.701(3)$ & Mo3-O2 & $1.690(3)$ \\
Mo1-O4 & $1.705(3)$ & Mo3-O11 & $1.740(3)$ \\
Mo1-O9 & $1.901(3)$ & Mo3-O5 & $1.940(3)$ \\
Mo1-O5 & $1.997(3)$ & Mo3-O6 & $1.960(3)$ \\
Mo1-O8 & $2.314(3)$ & Mo3-O8 & $2.167(3)$ \\
Mo1-O6 & $2.346(3)$ & Mo3-O8 & $2.358(3)$ \\
Mo2-O10 & $1.701(4)$ & Mo4-O1 & $1.693(4)$ \\
Mo2-O3 & $1.712(4)$ & Mo4-O13 & $1.696(3)$ \\
Mo2-O7 & $1.908(3)$ & Mo4-O7 & $1.896(3)$ \\
Mo2-O9 & $1.923(3)$ & Mo4-O6 & $2.016(3)$ \\
Mo2-O11 & $2.286(3)$ & Mo4-O8 ${ }^{\mathrm{i}}$ & $2.321(3)$ \\
Mo2-O8 & $2.462(3)$ & Mo4-O5 & $2.346(3)$ \\
\hline
\end{tabular}

Symmetry code: (i) $-x+1,-y+2,-z$.
Water molecules are linked in their turn through hydrogen bonds to the clusters with $\mathrm{OW}-\mathrm{H}$. . . O ranging from 1.899 to $2.458 \AA$.

These hydrogen bonds hold the components together into a three-dimensional supramolecular/hydrogen bonded network (figure 6) and make the crystal structure of the compound more stable. The details of hydrogen bonds are given in table 4 .

\subsection{Thermogravimetric Analyses}

The thermal gravimetric curve of $\left(\mathrm{C}_{2} \mathrm{H}_{6} \mathrm{~N}_{4}\right)_{2}\left[\beta-\mathrm{Mo}_{8}\right.$ $\left.\mathrm{O}_{26}\right] \cdot 4 \mathrm{H}_{2} \mathrm{O}$ (1) (figure $\mathrm{S} 2$ in Supplementary Information) exhibits one weight loss step in the temperature

Table 3. Bond valence sums $(\Sigma \mathrm{s})$ for compound $\mathbf{1}$.

\begin{tabular}{lcccc}
\hline Atom & Mo1 & Mo2 & Mo3 & Mo4 \\
\hline O1 & & & & 1.783 \\
O2 & & & 1.798 & \\
O3 & & 1.694 & & \\
O4 & 1.726 & & & \\
O5 & 0.784 & & 0.915 & 0.305 \\
O6 & 0.305 & & 0.867 & 0.745 \\
O7 & & 0.995 & & 1.030 \\
O8 & 0.333 & 0.223 & $0.495+0.296$ & 0.327 \\
O9 & 1.016 & 0.958 & & \\
O10 & & 1.745 & & \\
O11 & & 0.359 & 1.57 & \\
O12 & 1.745 & & & \\
O13 & & & & \\
O14 & & & $\mathbf{5 . 9 5 9}$ \\
$\sum_{\text {cal }} S_{i}$ & $\mathbf{5 . 9 0 9}$ & $\mathbf{5 . 9 7 6}$ & $\mathbf{5 . 9 4 1}$ & $+\mathbf{+ 6}$ \\
$\sum_{\text {the }} S_{i}$ & $+\mathbf{+ 6}$ & $+\mathbf{+ 6}$ & & \\
\hline
\end{tabular}




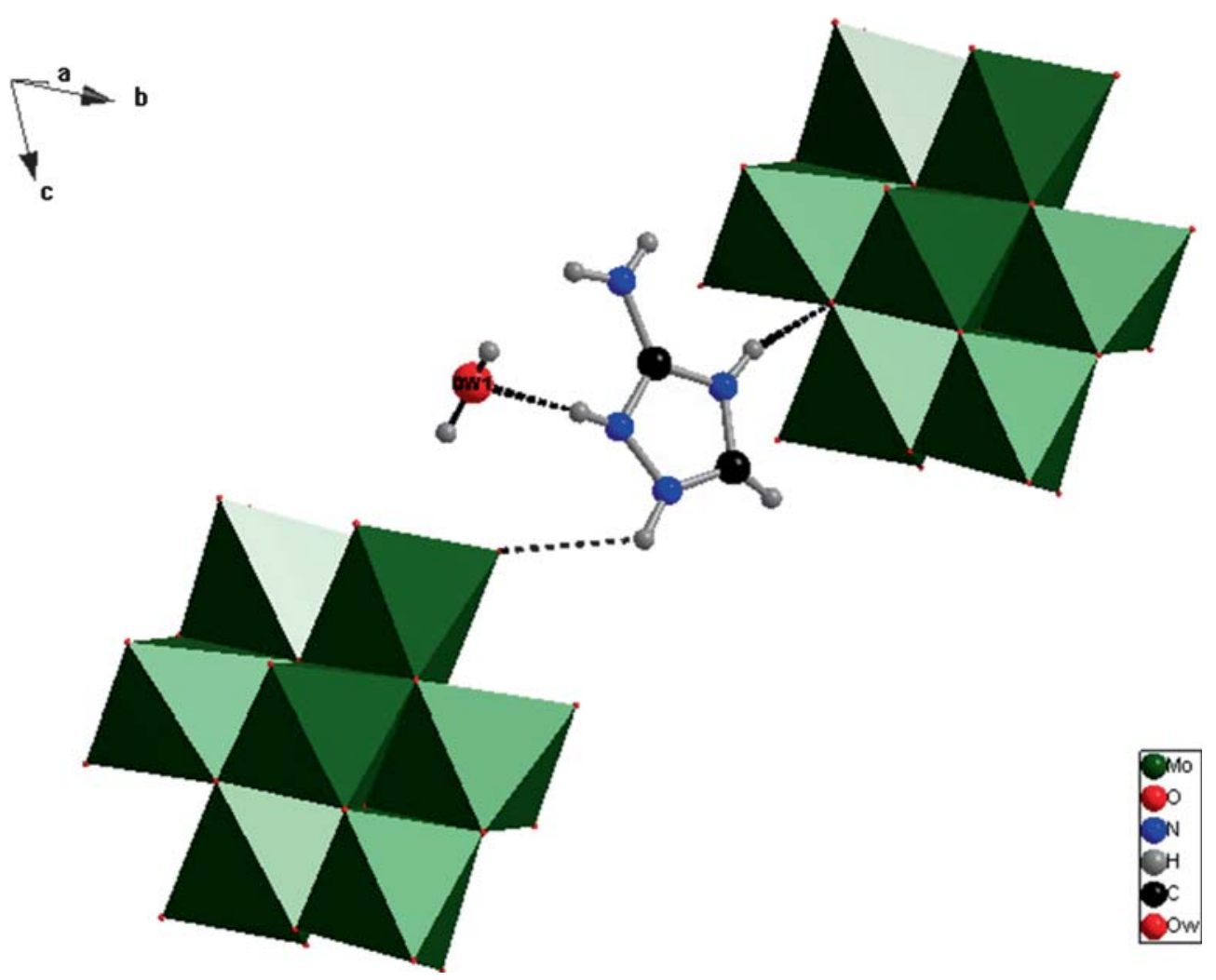

Figure 5. Polyhedral and ball-and-stick representation of the $\left[\mathrm{C}_{2} \mathrm{H}_{6} \mathrm{~N}_{4}\right]^{2+}$ environment in $\mathbf{1}$.

range $55-154^{\circ} \mathrm{C}$ corresponding to two endothermic peaks at 111 and $140^{\circ} \mathrm{C}$ are due to the dehydration of 4 water molecules. The observed weight loss $(4.75 \%)$ is in agreement with the calculated value $(5.04 \%)$. The second stage, which occurs from 263 to $378^{\circ} \mathrm{C}$, is attributed to the loss of two organic molecules, and two endothermic peaks at 288 and $364^{\circ} \mathrm{C}$ are attributed to this phase. The observed weight loss $(12.59 \%)$ is consistent with the calculated value $(12.68 \%)$. Above $400^{\circ} \mathrm{C}$, an exothermic phenomenon appears at $423^{\circ} \mathrm{C}$, probably due to the decomposition of the octa-molybdate.

\section{$3.3 \quad$ UV-Vis absorption}

The spectrum of compound $\mathbf{1}$ exhibits one maximum at $210 \mathrm{~nm}$ (figure S3 in SI). This characteristic band is ascribed to ligand-to-metal charge transfer from the oxygen $2 p$ orbital to the molybdenum $d$ orbital. ${ }^{27-29}$ The UV-Vis absorption spectra of the compound was measured to obtain his optical band gap $\left(E_{g}\right)$. The $E_{g}$ of the material was estimated from the absorption edge and using the Tauc relation, ${ }^{30}$ $(\alpha \mathrm{h} v)=\mathrm{A}\left(\mathrm{h} v-\mathrm{E}_{\mathrm{g}}\right)^{1 / 2}$, where $\mathrm{h} v$ is the absorbed photon energy and $\alpha$ is the corresponding absorption coefficient. The $\mathrm{E}_{\mathrm{g}}$ was obtained from extrapolation to $\alpha=0$ of the straight line portion in the plot of $(\alpha \mathrm{h} v)^{2}$ versus $\mathrm{h} v$ (inset in figure S3); the value was $4.7 \mathrm{eV}$ for 1 . This value is greater than the $\mathrm{Eg}$ value for $\mathrm{TiO}_{2},{ }^{31}$ which indicate that compound is insulating material.

\subsection{Electrochemical behavior}

The electrochemical study of $\left(\mathrm{C}_{2} \mathrm{H}_{6} \mathrm{~N}_{4}\right)_{2}\left[\beta-\mathrm{Mo}_{8} \mathrm{O}_{26}\right]$. $4 \mathrm{H}_{2} \mathrm{O}$ was carried out in $0.5 \mathrm{M}\left(\mathrm{CH}_{3} \mathrm{COONa} / \mathrm{CH}_{3}\right.$ $\mathrm{COOH}) \mathrm{pH}=4.8$ buffer $\left(2.10^{-3} \mathrm{~mol} \mathrm{~L}^{-1}\right)$ at a scan rate of 20 and $100 \mathrm{mV} / \mathrm{s}$, respectively. Figure S4 (in SI) shows the typical cyclic voltammetric (CV) behavior of 1. It can be clearly seen that in the potential range 1.3 to $-0.1 \mathrm{~V}$, one quasi-reversible redox peak appears and the mean peak potential $\mathrm{E}_{1 / 2}=\left(\mathrm{E}_{\mathrm{pa}}+\mathrm{E}_{\mathrm{pc}}\right) / 2$ is $0.26 \mathrm{~V}$ for 1. The redox peaks I-I' may be attributed to the redox of the $\mathrm{Mo}{ }^{\mathrm{VI} / \mathrm{V}}$ in the polyanion framework.

Cyclic voltammograms of $\mathbf{1}$ in same $\mathrm{pH}$ medium at different scan rates are shown in figure S5 in SI. The peak current of the title compound is linearly proportional to the square root of the scan rate as shown in the inset of figure S5. This indicates that the redox processes are diffusion-controlled. 


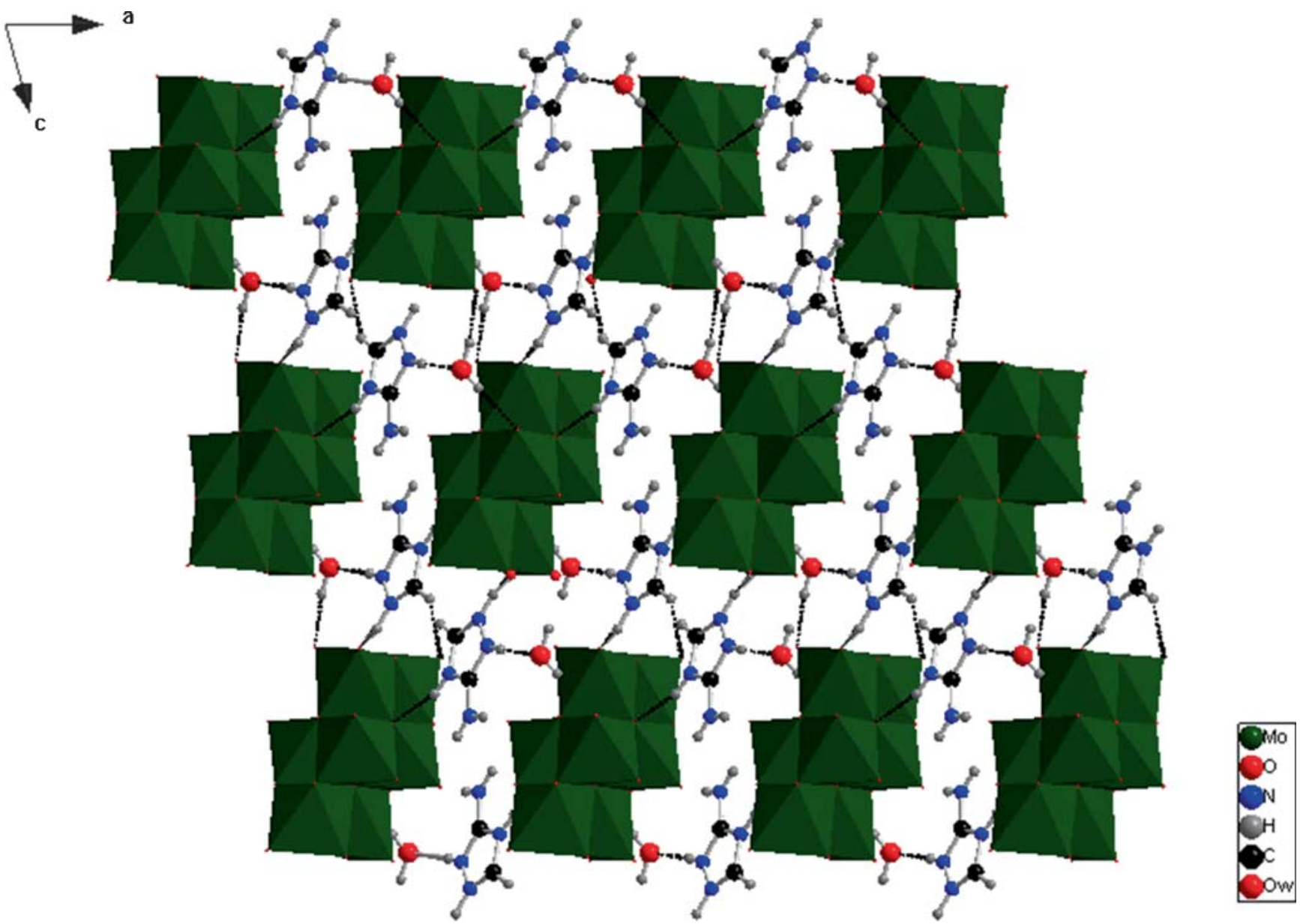

Figure 6. View of the 3-D supramolecular architecture of $\mathbf{1}$ by means of hydrogen bonding interactions.

Table 4. Hydrogen-bonding geometry $(\AA \stackrel{\circ}{\circ})$ for compound $\mathbf{1}$.

\begin{tabular}{|c|c|c|c|c|}
\hline $\mathrm{D}-\mathrm{H} \cdots \mathrm{A}$ & $\mathrm{D}-\mathrm{H}$ & $\mathrm{H} \cdots \mathrm{A}$ & $\mathrm{D} \cdots \mathrm{A}$ & $\mathrm{D}-\mathrm{H} \cdots \mathrm{A}$ \\
\hline $\mathrm{N} 1-\mathrm{H} 1 \cdots \mathrm{O} 12$ & 1.001 & 2.467 & 3.063 & 117.63 \\
\hline $\mathrm{N} 2-\mathrm{H} 2 \ldots \mathrm{OW} 1$ & 0.771 & 2.118 & 2.887 & 175.33 \\
\hline N4-H4 … O6 & 0.887 & 1.971 & 2.825 & 161.19 \\
\hline OW2-H6 . . O3 & 0.968 & 2.252 & 3.114 & 147.83 \\
\hline OW2-H6 ‥ O4 & 0.968 & 2.331 & 2.959 & 121.91 \\
\hline OW2-H7... O10 & 1.074 & 1.899 & 2.941 & 162.50 \\
\hline OW1-H8 . O O4 & 0.980 & 2.166 & 3.103 & 159.41 \\
\hline $\mathrm{OW} 1-\mathrm{H} 8 \cdots \mathrm{O} 12$ & 0.980 & 2.458 & 3.011 & 115.43 \\
\hline OW1-H9... O13 & 0.871 & 2.022 & 2.892 & 179.43 \\
\hline
\end{tabular}

\section{Conclusions}

In summary, we have successfully synthesized and characterized a new octa-molybdate-based hybrid compound, $\left(\mathrm{C}_{2} \mathrm{H}_{6} \mathrm{~N}_{4}\right)_{2}\left[\beta-\mathrm{Mo}_{8} \mathrm{O}_{26}\right] \cdot 4 \mathrm{H}_{2} \mathrm{O}(\mathbf{1})$; this contributes to the enriching of the chemistry of polyoxomolybdate. According to single-crystal structure analysis, the three-dimensional framework structure of the title compound is constituted of octa-molybdate units linked through several varieties of hydrogen bonding interactions. The cyclic voltammetry of compound $\mathbf{1}$ presents one reversible redox peak which is assigned to the redox of the molybdenum. The optical band gap of $\mathbf{1}$ indicates that this compound is potential wide-gap insulating material.

\section{Supplementary Information (SI)}

Crystallographic data with CCDC Numbers 1056979 for the structure reported in this paper has been 
deposited in the Cambridge Crystallographic Data Center and can be obtained free of charge via http://www. ccdc.cam.ac.uk/deposit, or from the Cambridge Crystallographic Data Centre, 12 Union Road, Cambridge CB2 1EZ, UK; fax: t(44) 01223336033 or e-mail to deposit@ccdc.cam.ac.uk. All additional information pertaining to characterization of the title compound 1 using IR spectroscopy (figure S1), thermogravimetric analysis (figure S2), UV-Vis absorption (figure S3), cyclic voltammetry measurements (figures S4 and S5) are given in the Supporting Information, available at www.ias.ac.in/chemsci.

\section{References}

1. Pope M T and Müller A 1994 In Polyoxometalates: From Platonic Solids to Antiviral Activity (Dordrecht, The Netherlands: Kluwer)

2. Pope M T and Müller A 1991 Angew. Chem. Int. Ed. 30 34

3. Proust A, Matt B, Villanneau R, Guillemot G, Gouzerh P and Izzet G 2012 Chem. Soc. Rev. 417605

4. Long D L, Tsunashima R and Cronin L 2010 Angew. Chem. Int. Ed. 491736

5. Yin P, Zhang J, Li T, Zuo X, Hao J, Warner A, Chattopadhyay S, Shibata T, Wei Y and Liu T 2013 J. Am. Chem. Soc. 1354529

6. Zheng S T and Yang G Y 2012 Chem. Soc. Rev. 41 7623

7. Song F, Ding Y, Ma B, Wang C, Wang Q, Du X, Fu S and Song J 2013 Energy Environ. Sci. 61170

8. Zebiri I, Boufas S, Mosbah S, Bencharif L and Bencharif M 2015 J. Chem. Sci. 1271769

9. Hagrman D, Zubieta C, Rose D J, Zubieta J and Haushalter R C 1997 Angew. Chem., Int. Ed. 36 873

10. Allis D G, Burkholder E and Zubieta J 2004 Polyhedron 231145

11. Allis D G, Raring R S, Burkholder E and Zubieta J 2004 J. Mol. Struct. 11688
12. Du X D, Li C H, Zhang Y, Liu S, Ma Y and You X Z 2011 Cryst. Eng. Comm. 132350

13. Wilson E F 2009 In Synthesis, structure and mechanism of polyoxometalate self-assembly: Towards designed nanoscale architectures (Glasgow: University of Glasgow) p.11

14. Hmida F, Ayed M, Ayed B and Haddad A 2015 J. Chem. Sci. 1271645

15. Shivaiah V 2006 Inorg. Chem. Commun. 91191

16. Li M X, Chen H L, Geng J P, He X, Shao M, Zhu S R and Wang Z X 2011 Cryst. Eng. Commun. 131687

17. Mascarós J R G and Martí-Gastaldo C 2007 Polyhedron 26626

18. Ray M S, Ghosh A, Chaudhuri S, Drew M G B and Ribas J 2004 Eur. J. Inorg. Chem. 153110

19. Kumagai H, Kepert C J and Kurmoo M 2002 Inorg. Chem. 413410

20. Cadiaua A, Adila K and Maisonneuve V 2011 Solid State Sci. 13151

21. CAD4, 1989 Solfware, version 5.0, Enraf Nonius, Delft, The Netherlands

22. North A C T, Phillips D C and Mathews F S 1968 Acta Cryst. 24351

23. Sheldrick G M 1997 SHELXS-97 Program for the solution of crystal structures (University of Göttingen: Germany)

24. Sheldrick G M 1997 SHELXL97 Program for the Refinement of Crystal Structures (University of Göttingen: Germany)

25. (a) Lindquist I 1959 Ark. Kemi 2 349; (b) Atovmyan L O and Krasochka O N 1972 Zh. Struct. Khim. 13 342; (c) Day V W, Fredrich M F, Klemperer W G and Shum W 1977 J. Am. Chem. Soc. 99952

26. Softbv web page by Pr. Stefan Adams, http://kristall.uni. mki.gwdg.de/softbv (accessed in February 2008)

27. Yamase T 1998 Chem. Rev. 98307

28. Zhang X M, Shen B Z, You X Z and Fun H K 1997 Polyhedron 1695

29. Gong Y, Hu C, Li H, Tang W, Huang K and Hou W 2006 J. Mol. Struct. $\mathbf{7 8 4} 228$

30. Tauc J, Grigorovici R and Vancu A 1966 Phys. Status Solidi B 15627

31. Fujishima A and Honda K 1972 Nature 37238 